\title{
Analysis of the genetic diversity in Metopolophium dirhodum (Walker) (Hemiptera, Aphididae) by RAPD markers
}

\author{
Marcelo Lopes-da-Silva ${ }^{1} \&$ Luiz Gonzaga Esteves Vieira²
}

${ }^{1}$ Curso de Agronomia e Ciências Biológicas, Universidade de Cruz Alta-UNICRUZ, 98025-810 Cruz Alta-RS, Brasil. mlopes@unicruz.edu.br ${ }^{2}$ Laboratório de Biotecnologia Vegetal, Instituto Agronômico do Paraná, Londrina-PR, 86001-970 Londrina-PR, Brasil. 1vieira@iapar.br

\begin{abstract}
Analysis of the genetic diversity in Metopolophium dirhodum (Walker) (Hemiptera, Aphididae). The emergence of host-races within aphids may constitute an obstacle to pest management by means of plant resistance. There are examples of host-races within cereals aphids, but their occurrence in Rose Grain Aphid, Metopolophium dirhodum (Walker, 1849), has not been reported yet. In this work, RAPD markers were used to assess effects of the hosts and geographic distance on the genetic diversity of $M$. dirhodum lineages. Twenty-three clones were collected on oats and wheat in twelve localitites of southern Brazil. From twenty-seven primers tested, only four primers showed polymorphisms. Fourteen different genotypes were revealed by cluster analysis. Five genotypes were collected only on wheat; seven only on oats and two were collected in both hosts. Genetic and geographical distances among all clonal lineages were not correlated. Analysis of molecular variance showed that some molecular markers are not randomly distributed among clonal lineages collected on oats and on wheat. These results suggest the existence of host-races within M. dirhodum, which should be further investigated using a combination of ecological and genetic data.
\end{abstract}

KEYWORDS. Rose-Grain Aphid; genetic diversity; host-races; insect-plant relationships.

RESUMO. Análise da diversidade genética de Metopolophium dirhodum (Walker) (Hemiptera, Aphididae) por meio de marcadores RAPD. A emergência de raças hospedeiro-especialistas em afídeos pode constituir um obstáculo ao manejo de pragas por meio de plantas resistentes. Existem exemplos de raças hospedeiro-especialistas em afídeos de cereais, embora a ocorrência de raça hospedeiro-especialista no pulgão-verde-pálido-do-trigo Metopolophium dirhodum (Walker, 1849) (Hemiptera, Aphididae) não tenha sido relatada ainda. Marcadores RAPD foram utilizados para avaliar os efeitos da distância geográfica e do hospedeiro sobre a diversidade genética de linhas clonais de $M$. dirhodum. Vinte e três clones foram coletados em aveia e trigo em doze localidades do sul do Brasil. De vinte e sete iniciadores usados para a análise, apenas quatro iniciadores mostraram polimorfismos. A análise de agrupamento por similaridade genética revelou haver quatorze genótipos, cinco dos quais coletados exclusivamente em trigo, sete exclusivamente em aveia e dois em ambos hospedeiros. Não houve correlação entre as similaridades genéticas e a distância geográfica. A análise da variância molecular demonstrou que alguns marcadores RAPD não se distribuem aleatoriamente entre as linhagens clonais coletadas em aveia e em trigo. Estes resultados sugerem a existência de raças hospedeiro-especialistas em M. dirhodum no Brasil, hipótese esta que deve ser investigada combinando-se dados ecológicos e genéticos.

PALAVRAS-CHAVE. Diversidade genética; interação inseto-planta; pulgão-amarelo-do-trigo; raças hospedeiroespecialistas.

Metopolophium dirhodum (Walker, 1849) is an important pest in cereals because of its damage on plants by sap suction and phytoviruses transmission. Poaceae are the host-plants of $M$. dirhodum in its asexual phase and this aphid is more often found in crops such as wheat, barley, rye, oats and maize (Dean 1974; Nicol et al. 1997). The presence of this aphid in South America was first recorded in 1970s in Chile and Brazil, when it became the major pest of wheat (Zuñiga 1986, Salvador 1999). In Brazil, M. dirhodum is more abundant in southern regions (Salvadori \& Tonet 2001) and there has not been any record of the occurrence of sexual phase (Lopes-da-Silva, personal information).

Fewer studies on the genetic diversity of $M$. dirhodum have been done compared to other cereals aphids worldwide. At molecular level, De Barro et al. (1995) did not found any association between genetic polymorphisms and host preference in this aphid in southern England. Nicol et al.(1997) found smaller genetic variability on recently introduced New Zealand populations of $M$. dirhodum than on Scotland populations of M. dirhodum. On other hand, in cytogenetics studies, Rubin-de-Celis et al. (1997) reported the presence of two karyotypes within this aphid in southern Brazil: $2 \mathrm{n}=16$ and $2 n=18$, suggesting an important genetic divergence caused by chromosomal arrangements.

The genetic diversity in aphids populations within a geographical region could be a result from natural selection imposed by hosts and from population division by migration (Loxdale 1990, De Barro et al.1997). Despite the high level of gene flow observed in some aphids, which prevent occurrence of geographically isolated populations in contiguous areas (Loxdale 1990), genetic structuring at micro geographical scale $(<1 \mathrm{~km})$ has been found in Metopolophium dirhodum (De Barro et al. 1995). However, host plant is considered the key factor responsible for genetic differences among sympatric aphid populations (Lushai et al. 2002). There are several reports of host-races within aphids that might be explained by selective pressures from host-plants (Diehl \& Bush 1984). Plant secondary metabolites are important defense against insect 
damage. Among them, phenolics have been described as major anti-herbivore compounds (Urbanska et al. 2002). Hydroxamic acids are the most important substance that promotes plant resistance by antibiosis against aphids (Givovich \& Niemeyer 1994). High level of these compounds are found in wheat and maize but are absent in oats and barley (Figueroa et al. 2002). The differential selective pressure caused by hosts with presence or absence of hydroxamic acids on the genetic composition of cereals aphids populations is still unknown (Figueroa et al. 2002).

Using RAPD markers to characterize twenty-three clonal lineages of $M$. dirhodum collected in different localities in southern Brazil, we evaluated the effect of host and geographical distance on the genetic diversity of this important cereal aphid.

\section{MATERIALAND METHODS}

Field Sampling. Twenty-three M. dirhodum clones were collected in wheat and oat fields in Paraná (PR) and Rio Grande do Sul (RS) (Table I). Field collects were performed from July to September (2001 and 2002).Clones from same locality were collected in the same crop field. A single individual from each field was used to establish a clonal lineage (putative clones) in greenhouse. For this, the samples were raised on wheat seedlings planted in $4 \mathrm{~L}$ pots protected by plastic tubes with their tops covered by a voil fabric in order to avoid parasitism by microhymenopterous.

DNA extraction. The DNA was extracted from five specimens from the each clonal lineage using Carvalho \& Vieira (2001) protocol with some modifications. The insect bodies were grounded manually in $60 \mu \mathrm{L}$ buffer extraction $(200 \mathrm{mM}$ Tris-HCl pH 8.0; $2 \mathrm{M} \mathrm{NaCl}$; 70mM EDTA pH 8.0) and $15 \mu \mathrm{L}$ of sarcosyl $(5 \%)$ was added. After incubation for $30 \mathrm{~min}$ at $65^{\circ} \mathrm{C}$ with occasional mixing, the extract was centrifuged at 10000 rpm for $15 \mathrm{~min}$ and the supernatant recovered to a new microtube. DNA was precipited by adding $110 \mu \mathrm{L}$ of ammonium acetate $(10 \mathrm{M})$ and $250 \mu \mathrm{L}$ of cold isopropanol to the aqueous supernatant. The solution was left overnight at $-20^{\circ} \mathrm{C}$ and centrifuged for $15 \mathrm{~min}$ at $10000 \mathrm{rpm}$. The pellet was washed with $70 \%$ ethanol, air, dried resuspended in $25 \mu \mathrm{L}$ of TE buffer (10mM Tris-HCl, 1 mMEDTApH 8.0) containing RNase (10mg/ $\mathrm{ml}$ ), and stored at $-20^{\circ} \mathrm{C}$. DNA concentration was estimated by fluorescence using DyNA Quant 200 minifluorimeter (Hoefer Instruments).

RAPD reactions. PCR for RAPD amplification were performed in $25 \mu \mathrm{L}$ aliquots containing approximately $25 \mathrm{ng}$ genomic DNA, 1 x PCR buffer[20mM Tris $\mathrm{HCl}(\mathrm{pH} 8,4), 50 \mathrm{mM}$ de $\mathrm{KCl}] 3.0 \mathrm{mM} \mathrm{MgCl}_{2}, 100 \mathrm{iM}$ of each dNTP, $0.5 \mathrm{iM}$ of primer and $1 \mathrm{U}$ de Taq DNA polymerase. The amplifications were performed in a PTC- $100^{\mathrm{TM}}$ (MJ Research, Inc.) using the following temperature program: $5 \mathrm{~min}$ at $94^{\circ} \mathrm{C}$ followed by 40 cycles of $1 \mathrm{~min}$ at $94^{\circ} \mathrm{C}, 90 \mathrm{~s}$ at $40^{\circ} \mathrm{C}$ and $2 \mathrm{~min}$ at $72^{\circ} \mathrm{C}$, with a final extension of $5 \mathrm{~min}$ at $72^{\circ} \mathrm{C}$. Amplification products were analyzed by electrophoresis at $5 \mathrm{~V} / \mathrm{cm}$ in agarose gel $(1.5 \%)$. The gel was stained with ethidium bromide solution $(1.0 \mathrm{mg} /$
Table I. Host-plants, localities, number and code for Metopolophium dirhodum clonal lineages collected on wheat and oats.

\begin{tabular}{lccc}
\hline Host-plant & Localities & Number of clones & Code \\
\hline \multirow{2}{*}{ Wheat } & Londrina-PR & 3 & W1 \\
& & & W2 \\
& Ponta Grossa-PR & 2 & W3 \\
& Ijuí-RS & & W4 \\
& Tapera-RS & 2 & W5 \\
Cruz Alta-RS & 1 & W6 \\
Oats & 1 & W8 \\
& Campo Mourão-PR & 1 & W9 \\
& Ijuí-RS & 1 & O1 \\
& Cruz Alta-RS & 3 & O3 \\
& & & O4 \\
& Panambi-RS & 3 & O5 \\
& & & O6 \\
& & & O7 \\
& Carazinho-RS & 1 & O9 \\
Passo Fundo-RS & 1 & O10 \\
Não-Me-Toque-RS & 2 & O11 \\
& & O12 \\
Ibirubá-RS & 1 & O13 \\
Selbach-RS & 1 & O14 \\
\hline
\end{tabular}

$\mathrm{ml}$ ) and photographed with KODAK EDAS 120 system.

Data Analysis. Only RAPD fragments (bands) less than $2.5 \mathrm{~kb}$ and reproducible in two or more gels were scored and considered for the analysis. A matrix of Jaccard's distances (Sneath \& Sokal 1973) were estimated between all pairs of twenty-three clonal lineages as follows: $\mathrm{S}=\mathrm{a} /(\mathrm{a}+\mathrm{b}+\mathrm{c})$ where: $\mathbf{a}$ is the number of bands present for both clonal lineages; $\mathbf{b}$, the number of bands present for a clonal lineage 1 but not for clonal lineage 2 and $\mathbf{c}$ the number of bands present for the clonal lineage 2, but not for clonal lineage 1 . The clustering procedure UPGMA - Unweighted Pair Group with Arithmetic Mean (Sneath \& Sokal 1973) was used to study the genetic relationships among the clones based upon distance matrix using NTSys 2.0 software (Rohlf 1998).

The genetic isolation by distance hypothesis was tested using Mantel test to correlate matrices of the genetic dissimilarity and geographic distance. Dissimilarity was obtained by the formula $\mathrm{DS}_{\mathrm{ab}}=1-\mathrm{S}_{\mathrm{ab}}$, where $\mathrm{DS}_{\mathrm{ab}}$ is dissimilarity index between a and $b$ and $S_{a b}$ is Jaccard's Similarity index between $a$ and $b$. To avoid the confounding effect of host and geographical distance on genetic diversity, the Mantel test was performed separately for clonal lineage according to the host.

A two-level Analysis of Molecular Variance (AMOVA) was performed to investigate the contribution of host-plant to the total genetic diversity (clonal lineage within hosts). AMOVAPREP(Miller 1998) and WINAMOVA 1.55 version (Excoffier $e t$ al., 1992) were used in this analysis. 


\section{RESULTS ANDDISCUSSION}

From the 27 RAPD primers tested, only four (OPA-2, OPA3 , OPA-4, OPA-7) showed clearly amplified DNA bands that were selected for analysis (Table II). A dendrogram is presented in Fig.1, where fourteen RAPD genotypes could be distinguished from the twenty-three clonal lineages. Five genotypes were observed exclusively in wheat; seven exclusively in oats and two were observed in both plants species. Considering the few RAPD markers obtained, these results revealed an unexpected high genetic diversity for a introduced parthenogenetic organism. This finding could be explained by variation of number of chromosomes set found in M. dirhodum specimens collected in Brazil (Rubin-de-Celis et al.1997). Different chromosome number within Rhopalosiphum maidis (Fitch) has been associated with host preference (Blackman et al.1990).

The association between genetic dissimilarity and geographic distance was $r=0.27 \quad(p=0.08)$ for clonal populations collected on wheat and $\mathrm{r}=-0.17(\mathrm{p}=0.13)$ for clonal lineages collected on oats. This indicated that spatial and genetic distances are not correlated and high genetic similarity between lineages is not a direct consequence of proximity between collection sites, which suggests absence of genetic isolation by distance, at least at macro-geographical scale. In Europe, aphids have high gene flow, which is a barrier to genetic structure formation by geographic isolation. (Loxdale 1990). However, De Barro et al. (1995) found genetic structure at micro geographic level and absence of association between genotypes and hosts for $M$. dirhodum in southern England. This surprising finding is related with occurrence of sexual phase in this region, which sexual recombination prevents disruptive selection effects caused by hosts (De Barro et al. 1995). On other hand, in New Zealand (as in Brazil), $M$. dirhodum has no sexual phase and there is no genetic structure at micro geographic level. (Nicol et al.1997).

The AMOVA analysis $\left(\Phi_{\mathrm{st}}=0.21 \mathrm{p}<0.001\right)$ indicated that there are significant differences between RAPD markers frequencies of clonal populations collected from wheat and oats. The genetic difference based on host-plant is considered the first criterion for host-race definition (Drès \& Mallet 2002). However, undoubted host-race identification depends on measuring performance and choice of the insects, reciprocally, in experiments for host-adaptation assessment (Lushai et al. 2002).

Table II. RAPD polymorphisms found within 23 clonal lineages of Metopolophium dirhodum using a set of four primers.

\begin{tabular}{lccc}
\hline Primer & $\begin{array}{c}\text { Total of } \\
\text { Reproducible } \\
\text { RAPD markers }\end{array}$ & $\begin{array}{c}\text { Number of RAPD } \\
\text { polymorphic } \\
\text { markers }\end{array}$ & $\begin{array}{c}\% \text { de } \\
\text { polymorphic } \\
\text { markers }\end{array}$ \\
\hline OPA-2 & 7 & 3 & $42,8 \%$ \\
OPA-3 & 9 & 2 & $22,2 \%$ \\
OPA-4 & 7 & 1 & $14,2 \%$ \\
OPA-7 & 7 & 4 & $57,1 \%$ \\
Total & 30 & 10 & $33,3 \%$ \\
\hline
\end{tabular}

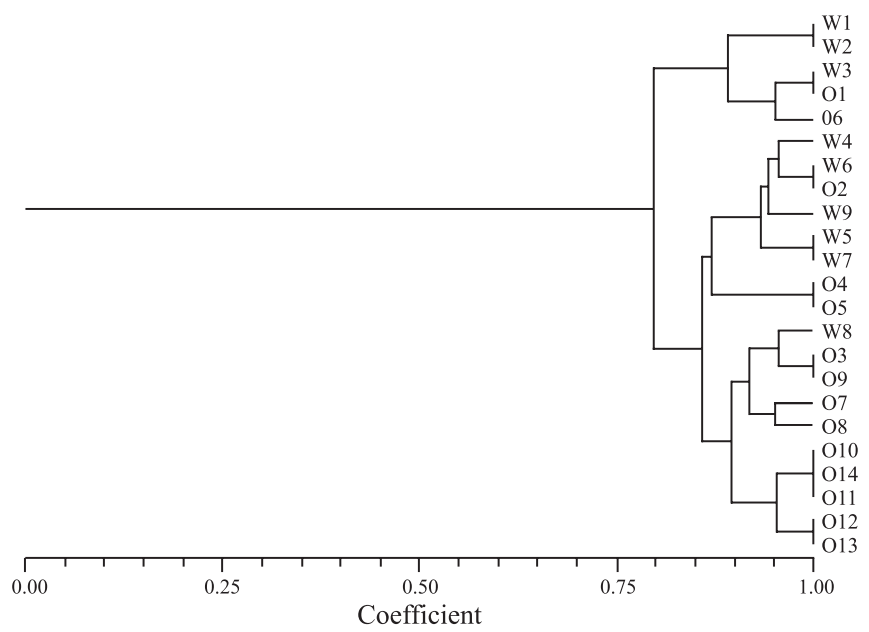

Fig.1. Dendrogram of genetic relationships among clonal populations of Metopolophium dirhodum using Jaccard Similarity Index (value 1.00 on $\mathrm{x}$-axis represents $100 \%$ of similarity). Codes for clonal lineages according to Table I.

Among RAPD polymorphisms, we found a strong association of $1.200 \mathrm{bp}$ marker obtained with OPA-4 primer and host (Fig.2). This marker was found in eleven out fourteen lineages collected on oats and only in one lineage collected from wheat.

Sunnucks et al (1997) also reported an almost perfect correlation between RAPD markers and host plants in studies with Therioaphis trifolii (Monell,1882). This 1200 bp may be only associated to a putative $M$. dirhodum "oat-race". The occurrence of a single clonal lineage in wheat could be result from random landing of alatae colonizers. Thus, aphids could be found on inadequate plant in early stages of hostcolonization (Hartworne \& Via 2001).

Within cereals aphids, Schizaphis graminum (Rondani, 1852) presents populations characterized in different biotypes, which are considered as highly divergent host-races (Anstead et al. 2002; Lopes-da-Silva et al. 2004) or complex species (Wilson et al. 2003). More recently, it has been proposed that

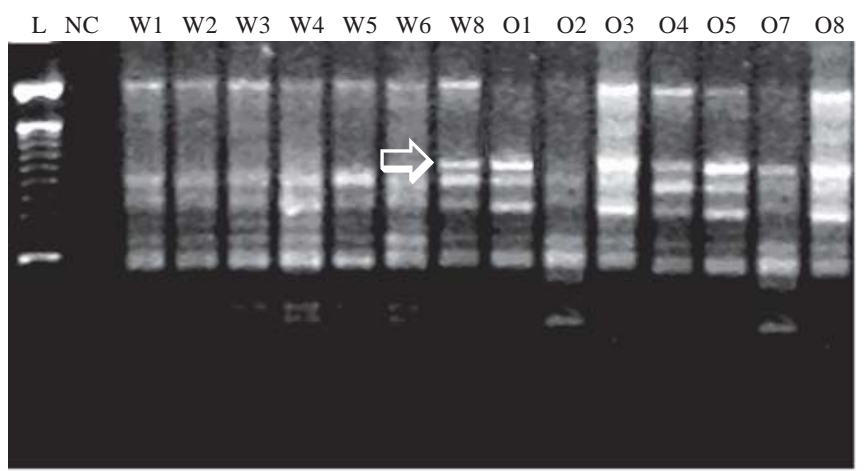

Fig. 2. RAPD profile of Metopolophium dirhodum clones obtained with use OPA-4 primer. White arrow is showing the marker (1200bp) more found in clonal lineages collected in oats (codes according to table I). 
Sitobion avenae has two host-races: "cocksfoot-race" and "wheat-race" those are genetically and ecological distinct (Lushai et al. 2002). Also, the population of this latter aphid is more genetically variable on wheat than on oats, which was attributed to the mutagenic effects of hydroxamic acids contained within wheat (Figueroa et al. 2002). Regarding M. dirhodum, there is no description of host-races within populations of this aphid.

Selection by the host plant better explains genetic differences among clonal lineages of $M$. dirhodum than geographical distances. Thus, we suggest that all or part of genetic differentiation within clonal lineages of this aphid could be related to the adaptation to the host-plant. The role of hyrdoxamic acids (present in wheat and absent from oat) as natural selection agent should be investigated in experiments comparing performance of clonal lineages genetically characterized, in both hosts. To our knowledge, this is the first report regarding the appraisal of the genetic variability of South American populations of Metopolophium dirhodum based on host.

\section{REFERENCES}

Anstead, J. A.; J. Burdon \& K. A. Shufran. 2002. Mitochondrial DNA sequence divergence among Schizaphis graminum (Hemiptera: Aphididae) clones from cultivated and non-cultivated hosts: haplotype and host associations. Bulletin of Entomological Research 92: 17-24.

Blackman, R. L.; S. Halbert, S. \& T. W. Carrol.1990. Association between karyotype and host plant in corn leaf aphid (Homoptera:Aphididae) in northwestern United States. Environmental Entomology 19: 609-611.

Carvalho, A. O. R. \& L. G. E. Vieira. 2001. Determinação das condições ótimas para análises de PCR-RAPD em Atta sexdens rubropilosa Forel (Hymenoptera:Formicidae). Neotropical Entomology 30: 593-600.

De Barro, P.; T. N. Sherrat; G. R. Carvalho; D. Nicol; A. Yengar \& N. McLean. 1995. The use of multilocus (GATA) ${ }_{4}$ probe to investigate geographic and microgeographic genetic structure variation in two aphid species over Southern England. Molecular Ecology 4: 375382.

Dean, G. J. W. 1974. The overwintering and abundance cereal aphids. Annals of Applied Biology 76: 1-7.

Diehl, S. R. \& G. L. Bush.1984. An evolutionary and applied perspective of insect biotypes. Annual Review of Entomology 29: 471504.

Drès, M. \& J. Mallet. 2002. Host races in plant feeding insects and their importance in sympatric speciation. Philosophical Transactions of Royal Society of London. B Biological Sciences 357: 471-92.

Excoffier, L.; P. E. Smouse \& J. M. Quattro.1992. Analysis of molecular variance inferred from metric distances among DNA haplotypes: application to human mitochondrial DNA restriction data. Genetics 131: 479-491.
Figueroa, C. C.; R. Loayza-Muro \& H. M. Niemeyer. 2002. Temporal variation of RAPD-PCR phenotype composition of the grain aphid Sitobion avenae (Hemiptera: Aphididae) on wheat: role of hydroxamic acids. Bulletin of Entomological Research 92: 25-33.

Givovich, A.; H. M. Niemeyer. 1994 Effect of hydroxamic acids on feeding behaviour and performance of cereal aphids (Hemiptera: Aphididae) on wheat. European Journal of Entomology 91: 371-374.

Hawthorne, D. J. \& S. Via.2001. Genetic linkage of ecological specialization and reproductive isolation in pea aphids. Nature 412: 904-907.

Loxdale, H. 1990. Estimating levels of genetic flow between natural populations of cereal aphids (Hemiptera: Aphdididae) Bulletin of Entomological Research 80: 331-338.

Lopes-da-Silva, M; G. E. L. Tonet \& L. G. E. Vieira. 2004. Characterization and genetic relationships among Brazilian biotypes of Schizaphis graminum (Rondani) (Hemiptera: Aphididae) using RAPD markers. Neotropical. Entomology 33: 43-49.

Lushai, G.; O. Markovitch \& H. D. Loxdale. 2002 Host-based genotype variation in insect revisited. Bulletin of Entomological Research 92: 159-164.

Miller, M. P. 1998. AMOVA-PREP freeware version 1.01 in mpm@nauvaux.ucc.nau.edu.

Nicol, D.; K. F. Armstrong; S. D. Wratten; C. M. Cameron; C. Frampton \& B. Fenton. 1997. Genetic variation in an introduced aphid pest (Metopolophium dirhodum) in New Zealand and relation to individuals from Europe. Molecular Ecology 6: 255-265.

Rohlf, F. J. 1998. NTSYSpc: Numerical Taxonomy System, ver. 2.0. Exeter publishing, Ltd.: Setauket, NY.

Rubin-de-Celis, V. R.; D. N. Gassen; M. C. Santos-Colares; A. K. Oliveira \& V. L. S. Valente. 1997. Chromosome studies in southern Brazilian wheat pest aphids Sitobion avenae, Schizaphis graminum, Methopolophium dirhodum (Homoptera:Aphididae). Brazilian Journal of Genetics 20: 415-419.

Salvadori, J. \& G. E. L. Tonet. 2002. Manejo integrado dos pulgões do trigo. EMBRAPA. Passo Fundo, 52 p.

Salvadori, J. R.1999. Controle biológico de pulgões de trigo: o sucesso que perdura. Passo Fundo: Embrapa Trigo, 1999. 2p.html. (Embrapa Trigo. Comunicado Técnico Online, 27). Disponível: http://www.cnpt.embrapa.br/biblio/p_co27.htm.

Sneath, P. H. A. \& R. R. Sokal. 1973. Numerical taxonomy: the principle and practice of numerical classification. V. H. Freeman, $537 \mathrm{p}$.

Sunnucks, P.; F. Driver; V. W. Brown; M. Carver; D. F. Hales \& W. M. Milne. 1997. Biological and genetic characterization of morphologically similar Therioaphis trifolii (Hemiptera:Aphididae) with different host utilization. Bulletin of Entomological Research 87: 425-436.

Urbanska, A.; B. Leszczynski; F. Tjallingi \& H. Matok. 2002. Probing behaviour and enzymatic defense of the grain aphid against cereal phenolics Electronic Journal of Polish Agricultural Universities, Biology 5 available on http://www.ejpau.media.pl/ series/volume 5/issue2/biology/art-02.html

Wilson, A. C. C.; P. Sunnucks \& D. F. Hales. 2003. Heritable genetic variation and potential for adaptative evolution in asexual aphids (Aphidoidea). Biological Journal of the Linnean Society 79: $115-135$.

Zuñiga, E. 1986. Control biológico de los afidos de los cereales en Chile. I. Revisión histórica y líneas de trabajo. Agricultura Tecnica 46: 475-477. 